\title{
Temporal changes in height and diameter growth for two Nothofagus species in New Zealand
}

\author{
Runkle, James R. ${ }^{1}$, Stewart, Glenn H. ${ }^{2}$ \& McClenahen, James R. ${ }^{3}$ \\ ${ }^{1}$ Department of Biological Sciences, Wright State University, Dayton, OH 45435, USA; \\ Fax+1 937775 3320; E-mail jrunkle@desire.wright.edu; ${ }^{2}$ Department of Plant Science, Lincoln University, P.O.Box 84, \\ Lincoln, Canterbury, New Zealand; ${ }^{3}$ Silvancare, P.O.Box 272, Shreve, OH 44676, USA
}

\begin{abstract}
We examined whether the growth dynamics of two species can explain their coexistence. In particular, we examined New Zealand forests dominated by Nothofagus fusca and $N$. menziesii to determine whether both species can reach the canopy in tree-fall gaps. Stems in a gap and other stems (in pairs: one of each species, close together) were destructively sampled and aged at their bases and at heights of $1.4 \mathrm{~m}$ and 3 $\mathrm{m}$, and at $2 \mathrm{~m}$ intervals thereafter as high as possible. For additional pairs of adjacent, similarly sized stems, one of each species, ring widths were analyzed for responsiveness to environmental changes. In general the faster growth rates of $N$. fusca were sufficient to balance the greater abundance of $N$. menziesii in the understory, such that both species were able to reach the canopy. Stems of both species grew at similar rates for decades. Both species were able to tolerate some periods of suppression and to respond to opportunities (climatic or due to mild disturbances).
\end{abstract}

Keywords: Competition; Disturbance; Forest; Height growth; Tree-fall gap; Tree-ring.

Nomenclature: Allan (1961).

\section{Introduction}

For two species to coexist, their life history attributes (abilities to grow, survive, reproduce) must be balanced within their shared environment such that both species can dominate some areas some of the time but neither can dominate all areas all of the time. A dynamic coexistence can be maintained if species differ primarily in their abilities to regenerate following disturbance. Such species differences can be important even for disturbance regimes dominated by small gaps, each formed by the death of one or a few individuals. Light, soil moisture, and other properties vary between gaps of different sizes and within gaps of the same size (see Veblen 1992 and review in Runkle et al. 1995). The ability of species to coexist by specializing on parts of these gradients (between and within gaps) has been termed 'gap partitioning' (Denslow 1980).
The present study examines differences between two tree species, Nothofagus fusca (red beech) and $N$. menziesii (silver beech), which together dominate large areas of forest in New Zealand. Compared to N. menziesii, $N$. fusca is less shade tolerant (measured both by growth and survival), grows faster in the open, has stronger apical dominance, grows larger (typically to $200 \mathrm{~cm}$ diameter and $30 \mathrm{~m}$ tall vs. $150 \mathrm{~cm}$ diameter and $25 \mathrm{~m}$ tall for N.menziesii), has shorter-lived leaves (1 yr vs. 3-5 yr), has a size distribution with relatively more large stems, and is more likely to occur as even-aged stands (Wardle 1984). Because of these differences, it has been proposed that $N$. fusca dominates following major disturbances whereas $N$. menziesii dominates in small gaps (Wardle 1984; Ogden 1988). However, both species persist in some areas even when disturbances have produced only small gaps for the last several centuries . $N$. menziesii has lower juvenile mortality but $N$. fusca has faster height growth rates and greater adult survivorship (Stewart \& Rose 1990). When gaps are formed, $N$. menziesii has an advantage over $N$. fusca because of its taller height in the understory. Whether $N$. fusca can reach the canopy depends on whether some of its many short seedlings can increase in height rapidly enough to overtop the taller N. menziesii Stewart et al. 1991). Growth rates for the two species vary with gap size, stem size, and position within gaps (Runkle et al. 1995). N. fusca grows better under constant, favorable conditions, such as at the center of gaps, where soil moisture and diffuse radiation are at their maximum. $N$. menziesii grows better near the south edge of gaps, where sunlight is more intense but probably more varied during the day due to shading by other stems. Growth rates for $N$. menziesii vary more with location than for $N$. fusca (Runkle et al. 1995).

Although many Nothofagus species in New Zealand hybridize, $N$. menziesii is in a different section of the genus than $N$. fusca and the two do not hybridize (Philipson \& Philipson 1988; Hill \& Read 1991).

We attempted to answer two questions concerning coexistence. First, are the initial (following disturbance) 
height and density advantages of $N$. menziesii in the understory sometimes but not always sufficient to let it reach the canopy before the faster growing $N$. fusca? Second, do the species differ in either the promptness or the magnitude of their response to environmental change?

Three data sets were used to address these questions. 1. All existing saplings in one tree-fall gap were felled. Cross sections of each stem at different heights were aged to determine the height profile of stems in the gap for different times in the past.

2. Canopy and tall understory stems were paired by species. Again, cross sections from different heights were aged.

3. Using basal cross sections of understory and small canopy stems paired by species and proximity, basal area changes were compared between members of each pair.

\section{Study area}

All sampling was done in unlogged stands in the Maruia Valley, South Island, New Zealand ( $42^{\circ} 13^{\prime} \mathrm{S}$, $172^{\circ} 16^{\prime} \mathrm{E}$ ), near areas studied for forest dynamics (Stewart \& Rose 1990; Duncan \& Stewart 1991; Stewart et al. 1991; Stewart \& Burrows 1994; Runkle et al. 1995). The stems used for the third data set mentioned above (basal sections of paired stems) came from plots 1 and 2 in Stewart \& Rose (1990). These forests contained from 175 to ca. 250 stems/ha of canopy sized individuals $(\geq 20 \mathrm{~cm} \mathrm{DBH}=$ diameter at breast height $=1.4 \mathrm{~m}$ ), of which most trees $>30 \mathrm{~m}$ tall and $>1 \mathrm{~m}$ DBH were $N$. fusca. Stands tended to be all-aged, with $N$. fusca dominants up to $400-450 \mathrm{yr}$ old. All stands occurred on terraces with soils formed from alluvial sand and silt overlying gravels containing variable mixtures of granite, greywacke, and schist (Bowen 1964; Mabin 1983). Hosking \& Kershaw (1985), Stewart \& Rose (1990), and Duncan \& Stewart (1991) describe past disturbance events (insects, drought, windstorms).

\section{Methods}

\section{Growth of saplings in gap}

A gap in the Maruia valley was sampled on November 17, 1988 (Fig. 1). The gap was selected to contain several saplings of each species and to be new enough to collect information on sapling growth before gap formation, and old enough to measure sapling growth after gap formation. It had $6^{\circ}$ slope and $305^{\circ}$ aspect. The orientation of the long axis of the gap (the same as the

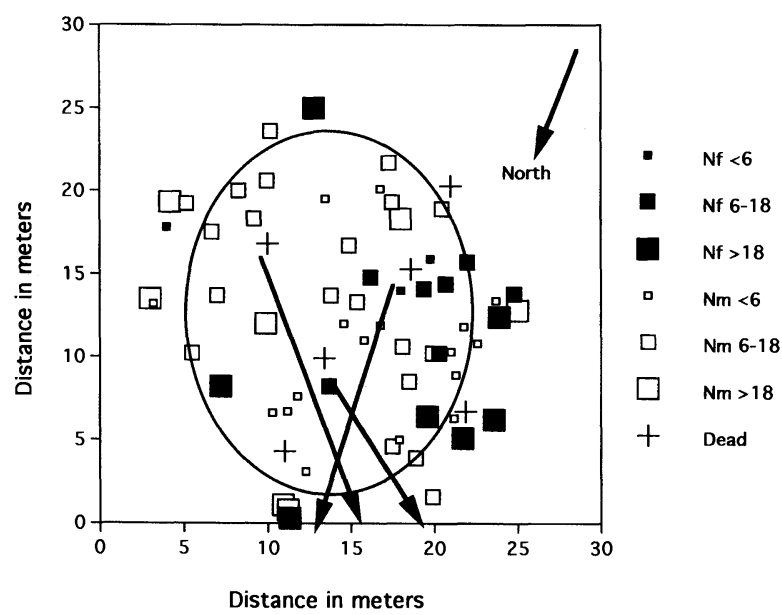

Fig. 1. Map of stems in a gap. Species codes are for $\mathrm{cm} \mathrm{DBH}$ classes. Arrows indicate main fallen stems. Ellipse indicates approximate border of canopy opening. $\mathrm{Nf}=N$. fusca, $\mathrm{Nm}=$ N. menziesii.

orientation of the fallen gapmakers, from base to top) was $333^{\circ}$. The height of the surrounding canopy was about $25 \mathrm{~m}$. Gap area was $406 \mathrm{~m}^{2}$ for the expanded gap (whose perimeter is set by the bases of canopy trees surrounding the canopy opening) and $243 \mathrm{~m}^{2}$ for the canopy gap (whose perimeter is set by a vertical projection of the canopy opening): gap shape was approximated as an ellipse defined by the largest two gap axes perpendicular to each other. For all living and dead stems within the gap and for the canopy trees surrounding the gap we recorded location (to nearest $0.1 \mathrm{~m}$, along two perpendicular axes), diameter at breast height, and height. We destructively sampled all 48 living stems within the gap. Complete disks were removed from each stem at the base, at breast height $(1.4 \mathrm{~m})$, and at $2 \mathrm{~m}$ intervals starting at height $3 \mathrm{~m}$ and continuing for the length of the stem. The 231 cross sections were air dried for several weeks and then sanded using 40,120, and 220 grit papers. The age of each section was read under a binocular microscope using a Henson tree-ring measuring machine.

We assumed that each ring represented one year's growth. Although Nothofagus sometimes has missing and/or false rings, most rings represent annual growth, especially in the faster growing, upper and outer sections of stems (Bussell 1968; Norton 1983; Norton \& Ogden 1987; Ogden et al. 1996).

We derived equations to predict stem height as a function of age for each stem. A stepwise procedure (Anon. 1990) was used to determine the best model for height as a function of some combination of $a$ (age), $a^{2}$, $a^{3}$ and $a^{4}$. These equations were used to estimate the 
height of each stem for several specific years. The predicted heights were combined to estimate the size distribution of stems in the gap for those years. Stems which had died before we sampled were not included. Our sample therefore is biased in favor of faster growing stems.

These equations also were used to calculate estimated stem heights at 20-yr intervals. Differences between these estimated heights were used to calculate frequency distributions of 20 -yr growth rates for both species. Species differences were evaluated using $t$-tests (Anon. 1990). An interval of $20 \mathrm{yr}$ should be long enough not to be influenced by short-term events, errors in reading rings or misleading outcomes of the equations. It should be short enough to generate a reasonable sample size and to be influenced by longer-term environmental changes.

A consistent significance level of $P<0.05$ will be used in this paper.

\section{Height growth of paired canopy stems}

Six pairs of small canopy trees, one $N$. fusca and one N. menziesii each, of approximately equal $\mathrm{DBH}$, were selected from the stand near the gap sampled (Table 1). Pairs of trees were selected to be close enough together to have undergone nearly the same climatic and disturbance history. Trees were destructively sampled and the age of each of the 105 sections estimated as above. Predictive equations relating height to age were developed, and used as for the gap saplings.

The diameters of other stems were sampled in plots of $10 \mathrm{~m}$ radius centered halfway between each pair of sampled stems. All stems were sampled which were $\geq$ half the diameter of the smaller of the two sampled trees. This criterion was used to include only stems most likely to influence the growth of the paired stems.

\section{Relative radial growth of paired stems}

Additional measurements were taken from two plots previously studied by Stewart \& Rose (1990). These plots were approximately $1 \mathrm{~km}$ apart in an old-growth forest near Station Creek, Rotoroa Ecological District, South Island. Data on those plots and discs of all stems $>1.4 \mathrm{~m}$ tall were collected at ground level in November/December 1986, shortly before the areas were commercially logged.

For the present study, we selected groups of stems (groups of two with one group of four) that fitted the following criteria: at least one individual of each species, stems similar in DBH and height, and in physical proximity $(<5 \mathrm{~m}$ apart). Altogether we examined 16 stems of each species, ranging $3.4-25.5 \mathrm{~cm} \mathrm{DBH}$ and $5.5-27.4 \mathrm{~m}$ high. Height and DBH did not vary significantly with species but were significantly larger in plot 1 (Table 2).

The basal discs from each stem were located and sanded as described above. Comparison of the individual ring-width series by the computer program COFECHA (Holmes 1983) revealed that the collection could not be cross-dated. This result precluded the use of standard tree-ring statistical analyses. Tree-ring widths were then converted to annual increments of basal area (BAI) using computer software developed by Phipps \& Fields (1988). BAI is the cross-sectional area of wood produced on the tree stem. The individual core series of BAI were then averaged for each species and plot.

Table 1. Paired canopy stems used for height-growth comparisons. $\mathrm{Nf}=$ Nothofagus fusca, $\mathrm{Nm}=$ N. menziesii.

\begin{tabular}{|c|c|c|c|c|c|c|c|c|c|}
\hline \multirow[b]{2}{*}{ Pair } & \multicolumn{2}{|c|}{$\mathrm{DBH}(\mathrm{cm})$} & \multicolumn{2}{|c|}{ ht (m) } & \multirow{2}{*}{$\begin{array}{c}\text { Distance between } \\
\text { stems }(\mathrm{m})\end{array}$} & \multirow{2}{*}{$\begin{array}{l}\text { Min. DBH for } \\
\text { plot sample }\end{array}$} & \multicolumn{3}{|c|}{ No. of living stems } \\
\hline & $N f$ & $\mathrm{Nm}$ & $N f$ & $\mathrm{Nm}$ & & & $N f^{1}$ & $\mathrm{Nm}^{1}$ & Other \\
\hline 1 & 20.3 & 18.8 & 24.5 & 22.5 & 2.3 & 9.4 & $8,4,3$ & $6,1,2$ & 0 \\
\hline 2 & 17.3 & 13.7 & 21.9 & 14.0 & 1.9 & 6.8 & $22,1,4$ & $11,3,0$ & 0 \\
\hline 3 & 10.2 & 10.1 & 16.3 & 10.6 & 2.5 & 5.1 & $6,4,3$ & $37,0,0$ & 0 \\
\hline 4 & 16.8 & 14.8 & 21.4 & 14.0 & 3.9 & 7.4 & $22,6,1$ & $8,2,1$ & 0 \\
\hline 5 & 10.0 & 9.0 & 13.7 & 13.3 & 2.3 & $*$ & & & \\
\hline 6 & 10.2 & 10.7 & 16.3 & 15.0 & 1.9 & 5.1 & $3,1,2$ & $34,9,1$ & 2 \\
\hline All & & & & & & & $61,16,13$ & $96,15,4$ & 2 \\
\hline
\end{tabular}




\section{Results}

\section{Growth of saplings in gaps}

The relationship of sapling or core height to measured age was significant for 43 of 48 stems and accounted for most of the variation in height (minimum $r^{2}$ $=0.88 ; r^{2} \geq 0.98$ for 37 of 48 stems). Gap saplings followed a variety of growth curves with many showing an increased growth rate in about 1900 (Fig. 2). Different parts of the gap were characterized by different growth patterns. In the center of the gap, stems of both N. fusca and N. menziesii originated about 1900 and
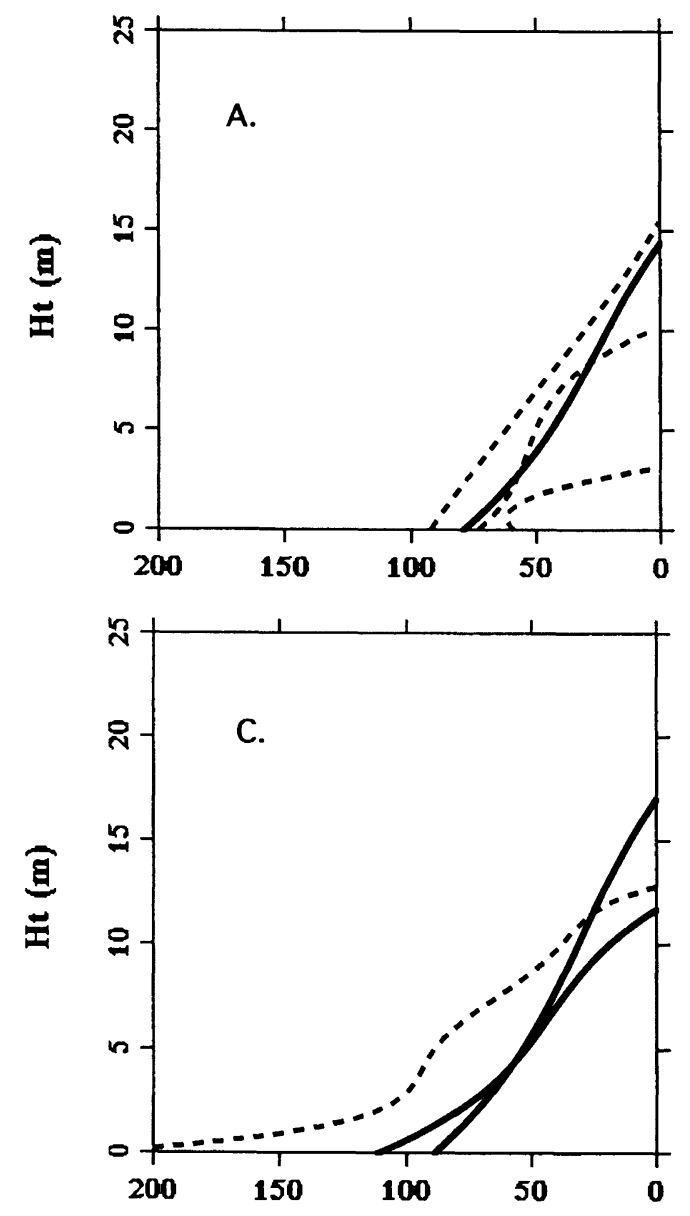

Age (yr before 1988)
Table 2. Size class distribution of stems used to measure relative radial growth of paired stems.

\begin{tabular}{lrcrrrr}
\hline Species & $\begin{array}{r}\text { DBH } \\
(\mathrm{cm})\end{array}$ & $\begin{array}{c}\text { Plot* }^{*} \\
\text { N. fusca }\end{array}$ & 2 & $\begin{array}{r}\text { Height } \\
(\mathrm{m})\end{array}$ & $\begin{array}{c}\text { Plot } \\
1\end{array}$ & 2 \\
& $<10$ & 1 & 6 & $<10$ & 0 & 6 \\
& $10-20$ & 5 & 2 & $10-20$ & 4 & 2 \\
& $\geq 20$ & 1 & 1 & $\geq 20$ & 3 & 1 \\
N. menziesii & $<10$ & 1 & 6 & $<10$ & 0 & 7 \\
& $10-20$ & 5 & 2 & $10-20$ & 5 & 1 \\
& $\geq 20$ & 1 & 1 & $\geq 20$ & 2 & 1
\end{tabular}

*Plots 1 and 2 in Stewart \& Rose (1990)
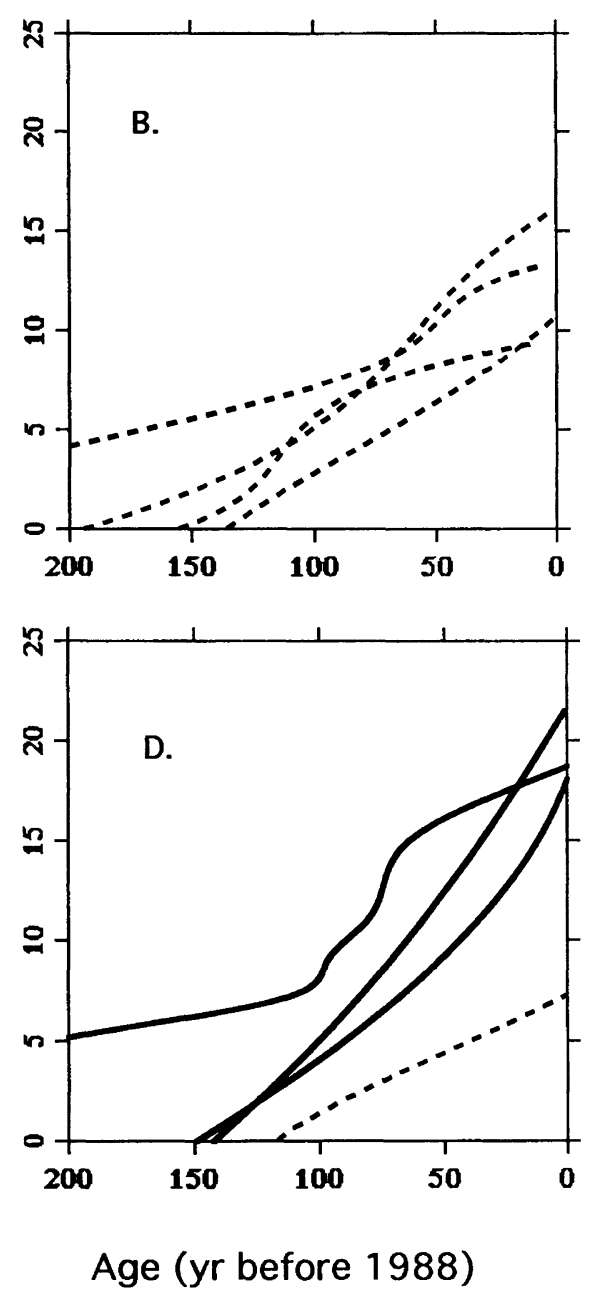

Fig. 2. Height growth curves for selected saplings in the gap. Solid lines $=N$. fusca, dashed lines $=N$. menziesii. Curves are polynomial, usually 3 rd order, fitted to actual height-age values. A. Fast growing stems in gap center. B. Slow and steady growth by stems in southeastern part of gap. C. Rapid and recent growth by previously suppressed stems in southwestern part of gap. D. Larger stems which had grown rapidly recently following suppression earlier in northwestern part of gap. 

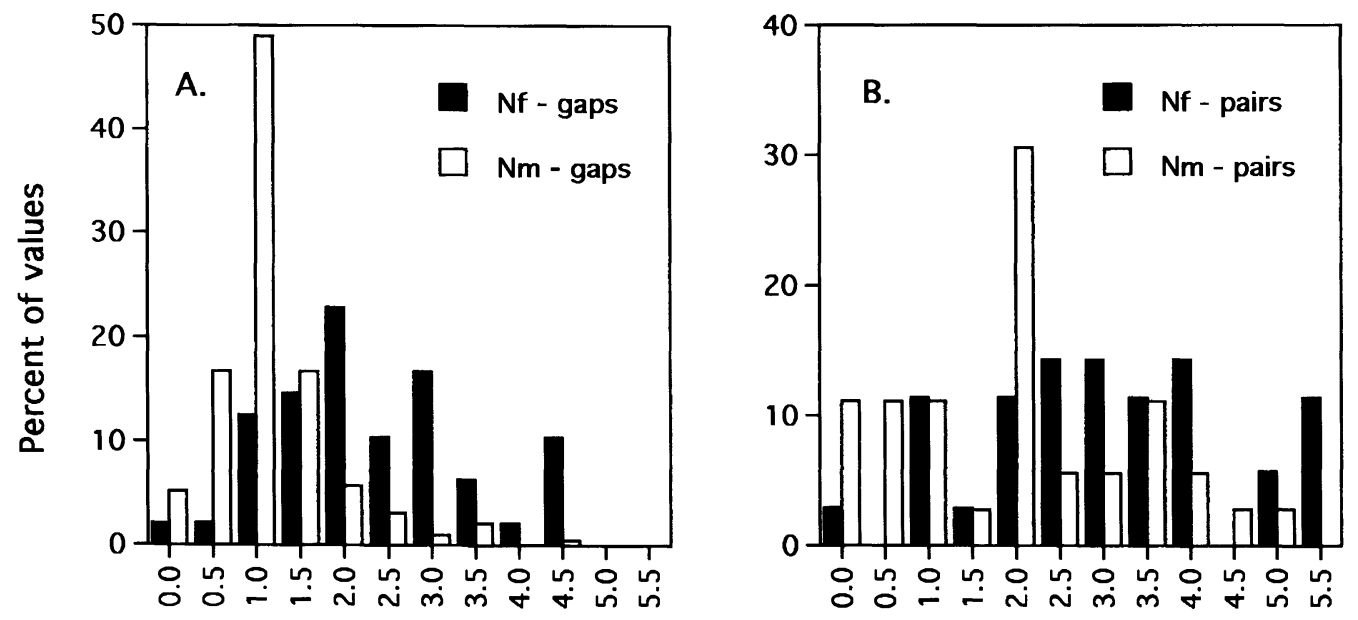

\section{Growth (m/20 yr)}

Fig. 3. Frequency distribution of $20-\mathrm{yr}$ simulated growth rates for both species A) in gaps and $\mathrm{B}$ ) as paired stems. $\mathrm{Nf}=N$. fusca; $\mathrm{Nm}=N$. menziesii .

either have grown fast ever since or slowed their growth when they became overtopped (Fig. 2A). The southeastern part of the gap is dominated by several large $N$. menziesii, which originated in the late 1700 s or mid1800 s and which have shown slow, steady growth (Fig. 2B). The southwestern part of the gap contains several stems which have grown rapidly since 1900 but which experienced some suppression earlier (Fig. 2C). The northwestern part of the gap contains some larger stems which also have grown relatively rapidly recently but which underwent some suppression earlier (Fig. 2D). In agreement with the literature (e.g. Wardle 1984) $N$. menziesii was more likely than $N$. fusca to have undergone long periods of suppression. $N$. fusca apparently usually grows relatively rapidly or dies. However, at least one stem of $N$. fusca did survive a lengthy suppression period (Fig. 2D). Some N. menziesii grew about as rapidly as $N$. fusca.

The patterns shown by these selected stems are representative of the pattern for all stems (Fig. 3). Although the ranges of $20-\mathrm{yr}$ growth intervals were similar for both species $(0.05-4.75 \mathrm{~m} / 20 \mathrm{yr}$ for $N$. fusca, $0.01-4.47 \mathrm{~m} / 20 \mathrm{yr}$ for $N$. menziesii), N. fusca growth was significantly greater and more variable $(N$. fusca: $n=48$, mean $=2.37$, S.D. $=1.11 ; N$. menziesii: $n$ $=192$, mean $=1.12$, S.D. $=0.68)$. Few stems of $N$. fusca showed the very slow growth rates common in $N$. menziesii. Few stems of $N$. menziesii showed the fast growth common in N. fusca.

The relative dominance of the two species in the gap changed over time, judging from the estimated height distributions (Fig. 4). At all times N. menziesii outnumbered $N$. fusca, especially among the smaller stems. This numerical advantage of $N$. menziesii is consistent with the literature (e.g. Stewart \& Rose 1990; Stewart et al. 1991; Ogden et al. 1996) and with the plots around the paired canopy trees used in this study (Table 1). However, N. fusca gradually increased among the taller stems in the gap. In 1889, the tallest 4 stems in the gap were N. menziesii. In 1988 the tallest 2 stems were $N$. fusca. Thus a competitive balance between the two species in this gap occurred because the greater initial height and numerical advantages of $N$. menziesii ensured that some of its saplings would reach the canopy while the faster growth of $N$. fusca ensured that some of its saplings also would reach the canopy.

Note that Fig. 4 does not include stems which died before we sampled.

\section{Height growth of paired canopy stems}

Stem or core height was significantly related to age for all 12 stems of $N$. fusca and N. menziesii picked to be close in DBH and in location and the relationship accounted for most of the variation (minimum $r^{2}=0.89 ; r^{2}$ $\geq 0.98$ for 10 of 12 stems). In 5 of 6 pairs N. menziesii was present before $N$. fusca and had an initial size advantage (Fig. 5). Eventually, however, in all cases, $N$. fusca grew taller. In part the larger size at present may be an artifact of the selection procedure: for a given DBH $N$. fusca usually will be taller than $N$. menziesii (Runkle et al. 1995). The growth rates of the two species were similar for many years for most pairs, with $N$. fusca 

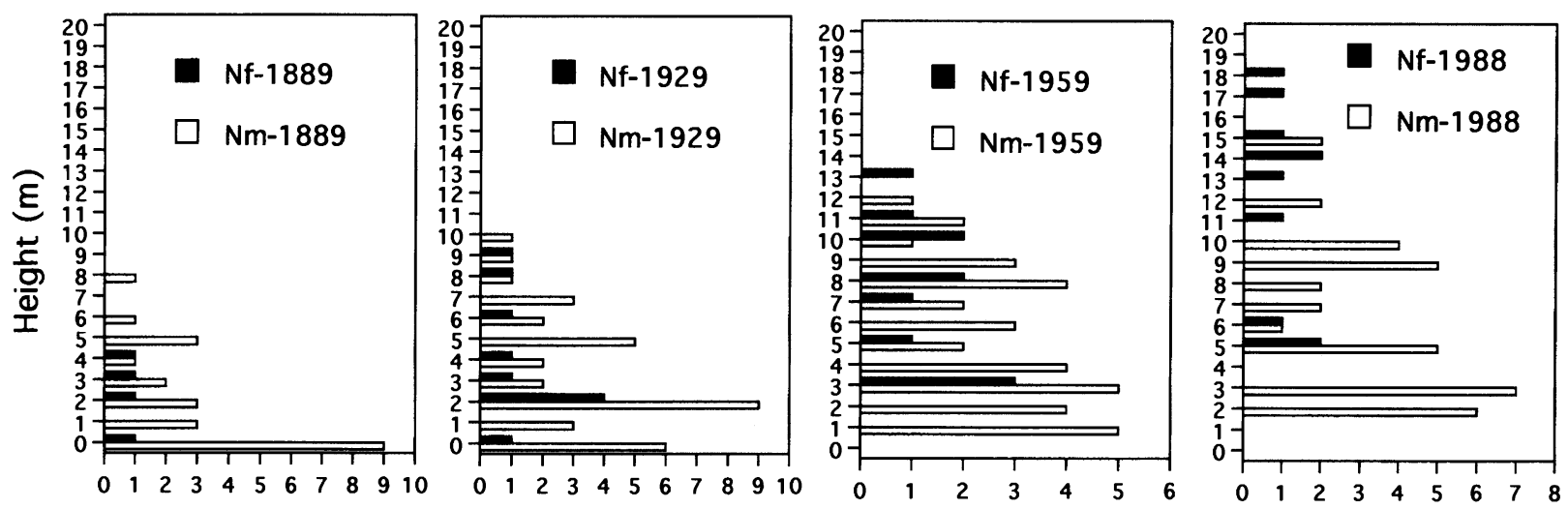

No. of Stems in Gap

Fig. 4. Estimated height distributions of saplings in the gap for four time periods for saplings alive in $1988 . \mathrm{Nf}=N$. fusca, $\mathrm{Nm}=N$. menziesii.

getting taller only in the last 20-50 years. Some errors estimating ages for the older, more slowly-growing sections of some stems were apparent: for some stems several cross sections in a row gave similar estimates of stem age. This problem was not nearly as important for the upper, more rapidly growing parts of the stem.

Both species had a wide range of values for $20-\mathrm{yr}$ growth (N. fusca: $0.20-7.59 \mathrm{~m} / 20 \mathrm{yr} ; N$. menziesii: 0.00 $4.90 \mathrm{~m} / 20 \mathrm{yr}$ ), with only one reading from $N$. fusca substantially greater than the maximum growth observed for $N$. menziesii (Fig. 3). Overall $N$. fusca growth was significantly faster than $N$. menziesii although not significantly more variable ( $N$. fusca: $n=35$, mean $=3.12$, S.D. $=1.55 ;$. menziesii: $n=36$, mean =1.98, S.D. $=1.30$ ).
Changes in the height distributions of these six pairs of stems over time match the results of the gap stems (Fig. 6). Once again, N. menziesii had an initial advantage which ensured that some stems would reach the canopy while the faster growth of $N$. fusca ensured that it also would be well represented in the canopy. The outcome of these relative advantages is that $N$. menziesii dominated the shorter size classes, though occasionally it reached the canopy, and $N$. fusca dominated the larger size classes (Table 1).
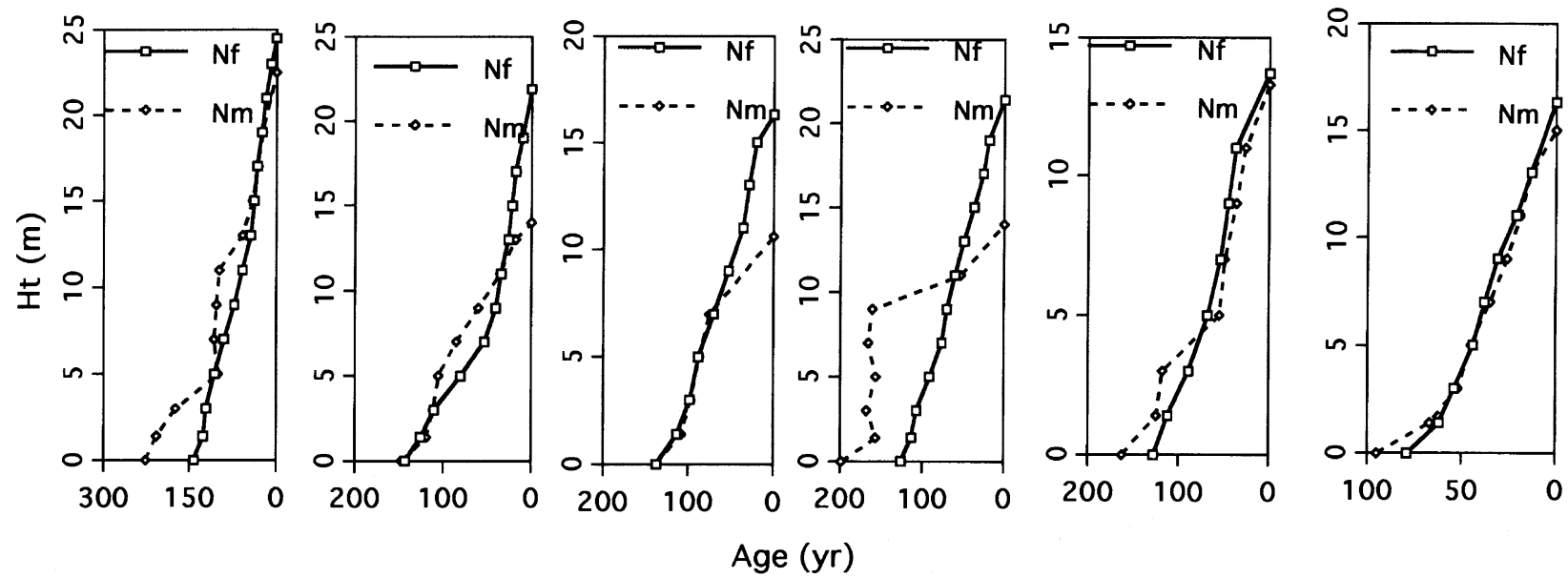

Fig. 5. Height growth curves for paired canopy stems. Pairs 1-6 are in order, left to right. $\mathrm{Nf}=N$. fusca, $\mathrm{Nm}=N$. menziesii. 

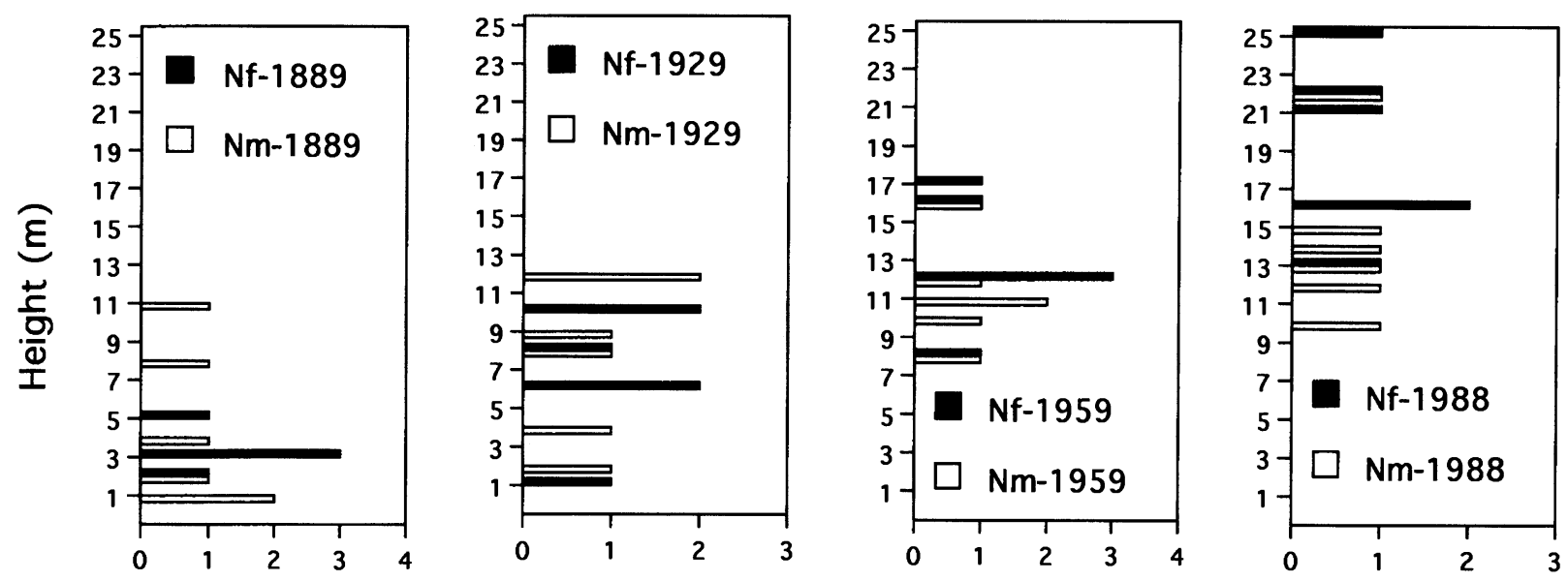

No. of paired stems

Fig. 6. Estimated height distributions for the paired canopy stems for four time periods. $\mathrm{Nf}=N$. fusca, $\mathrm{Nm}=N$. menziesii.

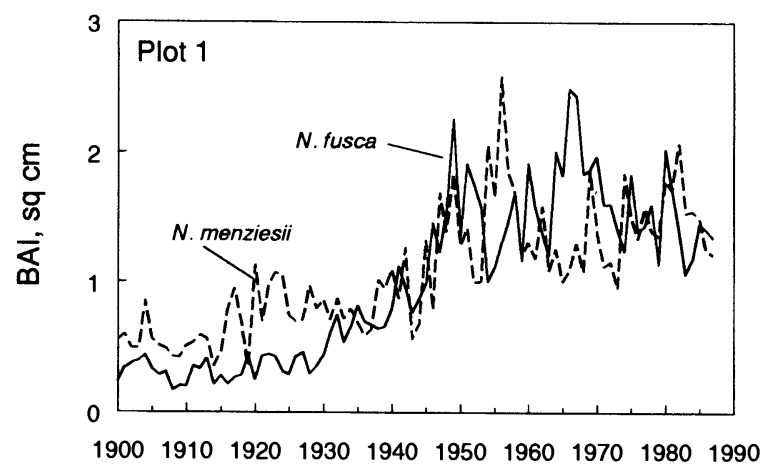

YEAR

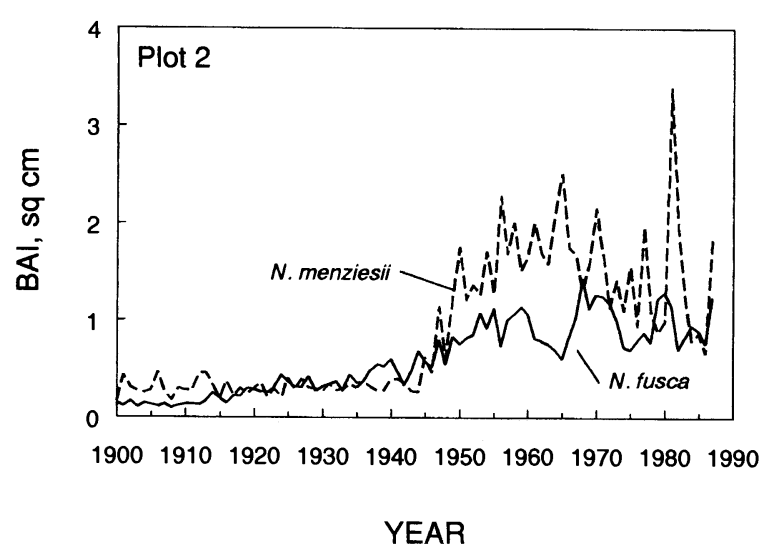

Fig. 7. Mean growth expressed as BAI (basal area increment) for $N$ fusca and $N$. menziesii since 1900. Solid lines $=N$. fusca, dashed lines $=N$. menziesii. A. Plot 1. B. Plot 2.
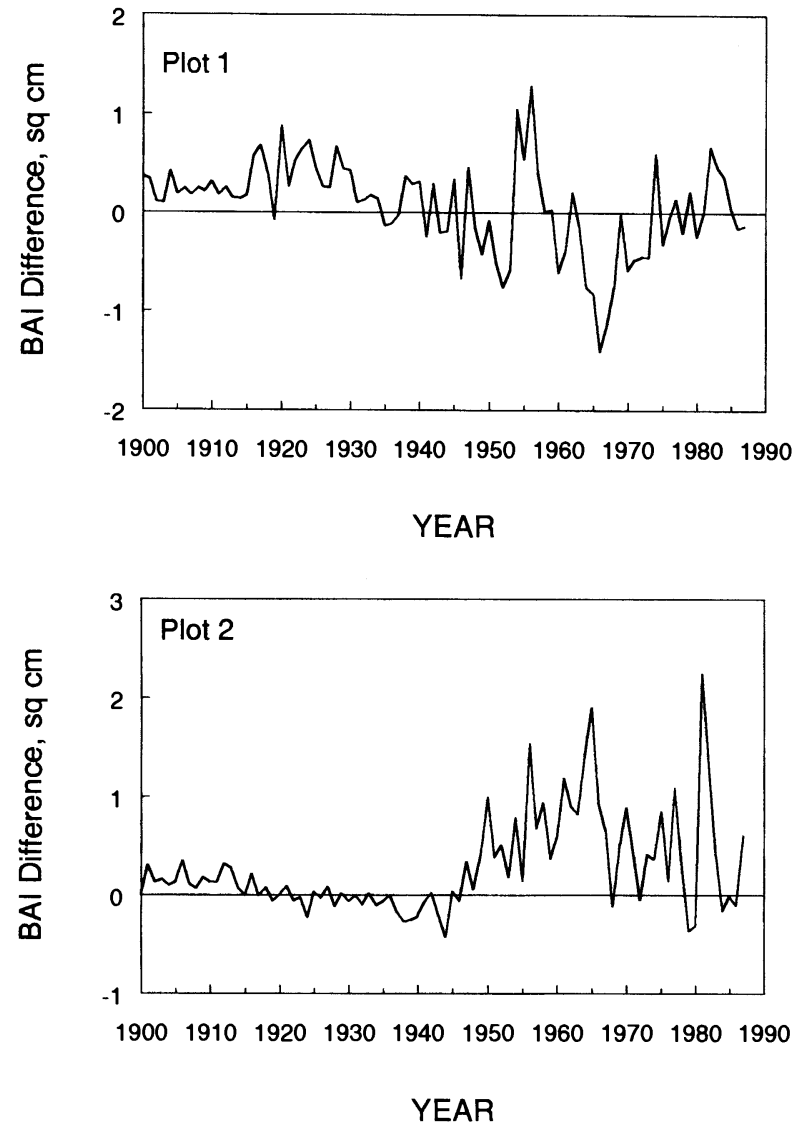

Fig. 8. Differences in mean basal area increments (BAI) since 1900. N. menziesii value minus N. fusca value. A. Plot 1. B. Plot 2. 


\section{Relative radial growth of paired understory stems}

The two species in plots 1 and 2 have grown differently since 1900 in response to the same disturbance regime (Figs. 7 and 8). Growth for both species in both plots was low in the early 1900s then increased about 1945, for both species in plot 1 and especially for $N$. menziesii in plot 2 (Fig. 7). This timing correlates with peaks in tree mortality from 1938-1951 in plot 1 and 1934-1955 in plot 2 (Stewart \& Rose 1990). Growth since 1945 has been high but variable for both species in both plots. In plot $1, N$. menziesii grew slightly but consistently faster than $N$. fusca during the period of slow growth (Fig. 8A). Since 1945 the relative growth rates have fluctuated greatly between years. In plot 2 both species grew at about the same, slow rate in the early 1900 s but since about $1945 N$. menziesii has grown consistently faster (Fig. 8B).

\section{Discussion}

Competition among forest trees usually occurs for light, soil moisture and nutrients (Cannell \& Grace 1993; Nambiar \& Sands 1993), although evidence from moist, temperate zone forests suggests that light has the strongest influence on sapling growth and survival (Pacala et al. 1994). Slight variations in light at $\geq 80 \%$ full shade affect relative growth and survival rates of coexisting saplings (Pacala et al. 1993, 1994; Peters et al. 1995). Tree species in temperate zone forests also respond to environmental differences between treefall gaps of different sizes and within single treefall gaps (Runkle 1985, 1990; Runkle \& Yetter 1987; Veblen 1992; McClure \& Lee 1993). Some species are better able to exploit temporal variation in light availability than others by hastening their induction responses to the light environment, e.g. to light flecks which appear over the leaves for only short periods (Poorter \& Oberbauer 1993).

$N$. fusca and N. menziesii differ in their light requirements. $N$. menziesii is the most shade tolerant of the New Zealand beeches (Manson 1974; Wardle 1984). The relative proportion of stems of $N$. menziesii and $N$. fusca in different size classes, as found here (Table 1) and by others, supports this generalization (Ogden 1985; Stewart \& Rose 1990; Stewart et al. 1991; Ogden et al. 1996). Typically, N. fusca is more abundant in small seedling size classes. However, high mortality results in the sapling and small tree size classes being dominated by $N$. menziesii. $N$. fusca often dominates the larger canopy size classes. $N$. menziesii is hypothesized to dominate the forest following small disturbances such as treefall gaps while $N$. fusca is thought to dominate after large-scale disturbances (Ogden 1988; Stewart \& Rose 1990; Ogden et al. 1996). This dichotomy is not absolute. $N$. menziesii is known to reproduce after both small and large disturbances, at least partly as a function of the environment: in wetter environments $N$. menziesii behaves more like N. fusca (Stewart 1986). N. fusca can reproduce both in gaps and after larger disturbances (Stewart et al. 1991; Runkle et al. 1995). Also, because both species disperse very slowly and therefore take a long time to reinvade areas from which they have been eliminated, it is unlikely that either has been excluded on a regular basis from locations where both are now present (Wilson \& Allen 1990; Leathwick \& Mitchell 1992; Ogden et al. 1996). The two species do differ in their fine-scale responses to light: $N$. fusca increases in relative importance as gap size increases; $N$. menziesii seems better able to take advantage of temporary (lasting minutes to hours) increases in light intensity south of gap center (Runkle et al. 1995).

$N$. fusca and N. menziesii differ in other ways which might explain their coexistence. $N$. fusca dominates sites which are better drained and richer in nutrients than those dominated by N. menziesii (Stewart et al. 1993; Ogden et al. 1996). Both species are sensitive to droughts but $N$. fusca is more sensitive (Manson 1974; Hosking \& Kershaw 1985).N. fusca is more sensitive to temperature extremes (Manson 1974; Ledgard \& Norton 1988). Both species can suffer damage from insects but $N$. fusca is more susceptible to pinhole borers, insects in general, and heart rots (Milligan 1974; Litchwark 1978; Hosking \& Kershaw 1985; Ledgard \& Norton 1988).

None of our sites had undergone recent large-scale disturbances. Hosking \& Kershaw (1985) reported massive mortality in 1978-1980 of $N$. fusca in areas near ours, probably caused by severe droughts in 1969-1971 and 1976-1978 followed by scale insect attacks. Stewart \& Rose (1990) found that small disturbances peaked about 1934-1955 in the plots from which some of our data come. These disturbances did not lead to the establishment of new stems but to increased growth by stems already present. Stewart et al (1991) found evidence of minor releases in several different periods from 1930 to 1981. Duncan \& Stewart (1991) used spatial correlations to indicate that tree mortality was clustered in groups of two to three trees (i.e. individual treefall gaps) within greater clusters, indicating that the same storm or season had led to several small gaps and probably other breakages too small to be detected.

Under this disturbance regime, the two species were balanced in their competitive abilities. For decades, stems of the two species grew at very similar rates to each other (Fig. 2). Both species survived long periods of suppression, although $N$. menziesii moreso than N. fusca (Fig. 2 ). Both species grew rapidly, although $N$. fusca more 
consistently than N. menziesii (Fig. 3). Both species reached the canopy, although $N$. fusca more often than $N$. menziesii (Table 1, Figs. 4 - 6). N. menziesii increased growth to take advantage of opportunities in the 1940s more than N.fusca, perhaps due to its increased resistance to insect damage and drought (Figs. 7 and 8).

The relative advantages of the two species varied over time. For some decades and years $N$. menziesii grew faster; for some, $N$. fusca grew faster. Conditions do not remain constant, especially since neither species is likely to reach the canopy in a single treefall gap (Ogden et al. 1991). Therefore, each stem experiences a continually changing environment. Changes in the environment may sometimes favor one species, sometimes the other. Because both species are shade tolerant, with low mortality rates, they each can survive a few years of unfavorable conditions, allowing both species to persist in the stand.

Acknowledgements. We thank Larry Burrows and Diane Carter for help in the field. We thank Dave Norton, Laura Conkey, Andi Lloyd and Robert Whitmoyer for assistance with tree ring analysis. Financial assistance for J.R. Runkle was received from $\mathrm{R}$. Kreps and the Research Council and College of Science and Mathematics of Wright State University. This study was also partially funded by the New Zealand Department of Conservation. Useful comments on the manuscript were received from J.B.Wilson and two anonymous reviewers.

\section{References}

Anon. 1990. SAS Procedures Guide. Version 6. 3rd. Ed. SAS Institute, Cary, NC.

Allan, H.H. 1961. Flora of New Zealand. Vol. 1. Government Printer, Wellington, N.Z.

Bowen, F.E. 1964. Sheet 15 - Buller (1st ed.). Geological Map of New Zealand 1:250 000. Department of Scientific and Industrial Research, Wellington.

Bussell, W.T. 1968. The growth of some New Zealand trees. 1. Growth in natural conditions. N.Z.J. Bot. 6: 63-75.

Cannell, M.G.R. \& Grace, J. 1993. Competition for light: detection, measurement, and quantification. Can. J. For. Res. 23: 1969-1979.

Denslow, J.S. 1980. Gap partitioning among tropical rainforest trees. Biotropica 12 (Supplement): 47-55.

Duncan, R.P. \& Stewart, G.H. 1991. The temporal and spatial analysis of tree age distributions. Can. J. For. Res. 21: 1703-1710.

Hill, R.S. \& J.Read. 1991. A revised infrageneric classification of Nothofagus (Fagaceae). Bot. J. Linn. Soc. 105: 37-72.

Holmes, R.L. 1983. Computer-assisted quality control in treering dating and measurement. Tree-Ring Bull. 43: 69-75.

Hosking, G.P. \& Kershaw, D.J. 1985. Red beech death in the Maruia Valley, South Island, New Zealand. N. Z. J. Bot. 23: 201-211.
Leathwick, J.R. \& Mitchell, N.D. 1992. Forest pattern, climate and vulcanism in central North Island, New Zealand. $J$. Veg. Sci. 3: 603-616.

Ledgard, N.J. \& Norton, D.A. 1988. Shoot growth in 2-3 year old Nothofagus seedlings. N. Z. J. Ecol. 11: 105-108.

Litchwark, H.S. 1978. Insect and fungal defects in red and silver beech. N. Z. J. For. Sci. 8: 259-266.

Mabin, M.C.G. 1983. The late Pleistocene glacial sequence in the middle Maruia valley, southeast Nelson, New Zealand. New Zeal. J. Geol. Geophys. 26: 85-96.

Manson, B.R. 1974. The life history of silver beech (Nothofagus menziesii). Proc. N.Z. Ecol. Soc. 21: 27-31.

McClure, J.W. \& Lee, T.D. 1993. Small-scale disturbance in a northern hardwoods forest: effects on tree species abundance and distribution. Can. J. For. Res. 23: 1347-1360.

Milligan, R.H. 1974. Insects damaging beech (Nothofagus) forests. Proc. N.Z. Ecol. Soc. 21: 32-40.

Nambiar, E.K.S. \& Sands, R. 1993. Competition for water and nutrients in forests. Can. J. For. Res. 23: 1955-1968.

Norton, D.A. 1983. Modern New Zealand tree-ring chronologies. II. Nothofagus menziesii. Tree-ring Bull. 43: 39-49.

Norton, D.A. \& Ogden, J. 1987. Dendrochronology: a review with emphasis on New Zealand applications. N.Z.J. Ecol. 10: 77-95.

Ogden, J. 1985. An introduction to plant demography with special reference to New Zealand trees. N.Z. J. Bot. 23: $751-772$.

Ogden, J. 1988. Forest dynamics and stand-level dieback in New Zealand's Nothofagus forests. GeoJournal 17: 225230.

$\rightarrow$ Ogden, J., Fordham, R.A., Pilkington, S. \& Serra, R.G. 1991. Forest gap formation and closure along an altitudinal gradient in Tongariro National Park, New Zealand. J. Veg. Sci. 2: 165-172.

Ogden, J., Stewart, G.H., \& Allen, R.B. 1996. Ecology of New Zealand Nothofagus forests. In: Veblen, T.T., Hill, R.S. \& Read, J. (eds.) The Ecology and biogeography of Nothofagus forests, pp. 25-82. Yale University Press, New Haven, CT.

Pacala, S.W., Canham, C.D., \& Silander, J.A. 1993. Forest models defined by field measurements: I. The design of a northeastern forest simulator. Can. J. For. Res. 23: 19801988.

Pacala, S.W., Canham, C.D., Silander, J.A. \& Kobe, R.K. 1994. Sapling growth as a function of resources in a north temperate forest. Can. J. For. Res. 24:2172-2183.

Peters, R., Tanaka, H., Shibata, M. \& Nakashizuka, T. 1995. Light climate and growth in shade-tolerant Fagus crenata, Acer mono and Carpinus cordata. Ecoscience 2: 67-74.

Philipson, W.R. \& Philipson, M.N. 1988. A classification of the genus Nothofagus (Fagaceae). Bot. J. Linn. Soc. 98: 27-36.

Phipps, R.L. \& Fields, M.L. 1988. Basal area increment programs. Tree-Ring Laboratory, U.S. Geologic Survey, Reston, VA.

Poorter, L. \& Overbauer, S.F. 1993. Photosynthetic induction responses of two rainforest tree species in relation to light environment. Oecologia (Berl.) 96: 193-199.

Runkle, J.R. 1985. Disturbance regimes in temperate forest. In: 
Pickett, S.T.A. \& White, P.S. (eds.) The ecology of natural disturbance and patch dynamics, pp. 17-33. Academic Press, New York, NY.

Runkle, J.R. 1990. Gap dynamics in an Ohio Acer-Fagus forest and speculations on the geography of disturbance. Can. J. For. Res. 20: 632-641.

Runkle, J.R. \& Yetter, T.C. 1987. Treefalls revisited: gap dynamics in the southern Appalachians. Ecology 68: 417424.

$\rightarrow$ Runkle, J.R., Stewart, G.H. \& Veblen, T.T. 1995. Sapling diameter growth in gaps for two Nothofagus species in New Zealand. Ecology 76: 2107-2117.

Stewart, G.H. 1986. Forest dynamics and disturbance in a beech/hardwood forest, Fiordland, New Zealand. Vegetatio 68: 115-126.

Stewart, G.H. \& Burrows, L.E. 1994. Coarse woody debris in old- growth temperate beech (Nothofagus) forests of New Zealand. Can. J. For. Res. 24: 1989-1996.

Stewart, G.H. \& Rose, A.B. 1990. The significance of life history strategies in the developmental history of mixed beech (Nothofagus) forests, New Zealand. Vegetatio 87: 101-114.

Stewart, G.H., Basher, L.R., Burrows, L.E., Runkle, J.R., Hall, G.M.J., \& Jackson, R.J. 1993. Beech-hardwood forest composition, landforms, and soil relationships, North Westland, New Zealand. Vegetatio 106: 111-125.

Stewart, G.H., Rose, A.B. \& Veblen, T.T. 1991. Forest development in canopy gaps in old-growth beech (Nothofagus) forests, New Zealand. J. Veg. Sci. 2: 679-690.

Veblen, T.T. 1992. Regeneration dynamics. In: GlennLewin,A.C., Peet, R.K. \& Veblen, T.T. (eds.) Plant Succession: Theory and Predictions, pp. 152-187. Chapman and Hall, London.

Wardle, J. 1984. The New Zealand Beeches: Ecology, Utilisation and Management. New Zealand Forest Service, Christchurch.

Wilson, J.B. \& Allen, R.B. 1990. Deterministic versus individualistic community structure: a test from invasion by Nothofagus menziesii in southern New Zealand. J. Veg. Sci. 1: 467-474. 